\title{
FULLFILMENT: SEBUAH TINJAUAN HISTORIKAL-TEOLOGIS
}

Made Nopen Supriadi

madenopensupriadi@sttab.ac.id

\begin{abstract}
The study of eschatology is inseparable from the concept of fulfillment. What will be fulfilled at the end of time? Then who is the person who will fulfill everything at the end of time? Therefore, to give an understanding to believers about the teaching of fullfilment, this paper will explore Biblically and formulate systematically by looking at the views of the theologians who wrote the topic.
\end{abstract}

Keywords: Fullfilment, Theological.

Abstrak: Studi mengenai eskatologi tidak terlepas dari konsep penggenapan (Fullfilment). Apakah yang akan digenapi pada akhir zaman? Lalu siapakah tokoh yang akan menggenapi segalanya pada akhir zaman? Oleh karena itu untuk memberikan pemahaman kepada orang percaya mengenai ajaran fullfilment, maka melalui tulisan ini akan menggali secara Biblical dan merumuskan secara sistematis dengan melihat pandangan theolog-theolog yang menuliskan topik tersebut.

Kata Kunci: Fullfilment, Teologis.

\section{PENDAHULUAN}

Eskatologi adalah doktrin tentang akhir zaman. Fullfilment adalah penggenapan yang dipelajari dalam eskatologi. Istilah fullfilment ada dalam Alkitab, dan digunakan dalam theologi sistematika. Pembahasan secara biblika dengan meninjau ayat-ayat tentang fulfillment dan menyusun data tersebut secara sistematis untuk mengerti ajaran tentang fullfilment. Dalam penulisan akan membahas etimologi dan definisi dari fullfilment menurut Alkitab secara khusus dalam teologi sistematika mengenai eskatologi. Dan pembahasan setiap bab berdasarkan point-point dari definisi fullfilment.

\section{ETIMOLOGI}

Istilah fullfilment memiliki arti penggenapan dan pemenuhan. ${ }^{1}$ Istilah

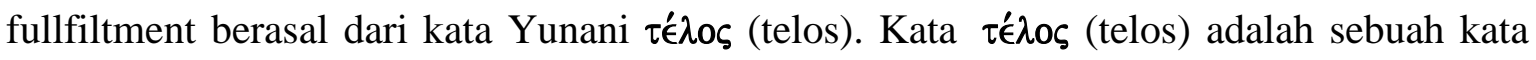
yang ditulis dari bahasa Yunani klasik dan di dalam LXX (septuaginta) serta di dalam Alkitab Perjanjian Baru (PB), kata tersebut juga sering diartikan dengan completion (penyelesaian), conclusion (kesimpulan), goal to end (tujuan akhir), end of the world (akhir dari dunia), dan died (meninggal). Pengertian kata tersebut juga sama dalam teks Alkitab PB. Dalam teks Alkitab PB kata $\tau$ ‘́ $\lambda$ os (telos) ditulis 40 kali memiliki arti akhir, kesimpulan, tujuan, hasil, akhirnya, sepenuhnya, sisanya, dan bea (lih. Mat. 10:22; 17:25; 24:6; 24:13; 24:14; 26:58; Mrk. 3:26; 13:7; 13;13, Luk. 1:33; 18:5; 21:9; 22:37, Yoh. 13:1, Rm. 6:21; 6:22; 10:4; 13:7, 1Kor.1:8; 10:11; 15:24, 2Kor.1:13; 3:13; 11:15, Flp. 3:19,

\footnotetext{
${ }^{1}$ Henk Ten Napel, Kamus Theologi (Jakarta: BPK Gunung Mulia, 2002), hal. 144
} 
1Tes.2:16, 1Tim. 1:5, Ibr. 3:14; 6:8; 6:11; 7:3, Yak. 5:11, 1Pet. 1:9; 3:8; 4:7; 4:17, Why. $2: 26 ; 21: 6 ; 22: 13)^{2}$

Istilah yang menunjuk pada penggenapan juga ditulis dengan kata plh,rwma (pleroma). Kata pleroma ditulis 17 kali dalam Alkitab Perjanjian Baru, kata tersebut memiliki arti apa yang memenuhi, pelengkap, tambalan, dia yang dipenuhi, jumlah seluruhnya, kelimpahan, jumlah yang lengkap, pemenuhan, keadaan yang penuh, yang penuh, yang lengkap (lih. Mat. 9:16, Mrk. 2:21;6:43;8:20, Yoh. 1:16, Rm. 11:12; 11:25; 13:10; 15:29, 1Kor. 10:26, Gal. 4:4, Ef. 1:10; 1:23; 3:19; 4:13, Kol. 1:19; 2:9). ${ }^{3}$ Kata pleroma menyiratkan pengertian tentang pemenuhan, yaitu proses menuju penggenapan. ${ }^{4}$ Jadi istilah pleroma tidak digunakan pada penggenapan tetapi menunjuk pada proses penggenapan.

\section{TERMINOLOGI}

Penggenapan menunjuk pada kata te,loj (telos) dalam bahasa Inggris fullfilment yang memiliki arti penggenapan. Dalam Kamus Besar Bahasa Indonesia (KBBI) kata penggenapan dari kata dasar genap yang merupakan kata sifat yang berarti tidak terbagi, tidak terpecah, utuh, penuh, sudah tidak kurang lagi, tidak ganjil, habis dibagi dua, pantas dan cocok. ${ }^{5}$

Dalam konteks eskatologi istilah fullfilment (penggenapan) menunjuk pada person dan karya Yesus Kristus. Namun penggenapan yang dilakukan oleh Yesus Kristus bersifat progresif berdasarkan konteks Alkitab dimulai dari PL sampai PB, dalam konteks eskatologi bersifat futuris sampai pada kedatangan-Nya yang kedua kali. Kata te,loj (telos) disimpulkan dalam Exegetical Dictionary Of The New Testament menunjuk pada penggenapan akhir dari dunia (lih. Mat. 24:6; 24:14, Mrk.13:7, Luk. 21:9, 1Kor. 10:11, 1Pet. 4:7, Why. 2:26) dan penggenapan Yesus Kristus atas hukum Taurat (Rm. 10:4). ${ }^{6}$ Beberapa Theolog juga menjelaskan tentang penggenapan yang menunjuk pada penggenapan kedatangan Yesus Kristus. ${ }^{7}$ Jadi fullfilment atau penggenapan adalah

\footnotetext{
${ }^{2}$ Hasan Sutanto, Perjanjian Baru Interlinear Yunani-Indonesia dan Konkordansi Perjanjian baru (PBIK) Jilid II (Jakarta: LAI, 2010), hal. 750

3 Ibid,..., hal. 648

4 Anthony A. Hoekma, Alkitab Dan Akhir Zaman (Surabaya: Momentum: 2004), hal. 20

5 Tim Prima Pena, KBBI, (....: Gita Media Press,....), hal. 287

6 Horst Balzt dan Gerhard Schneider, Exegetical Dictionary Of The New Testament (EDNT) (Nichigan: Wiiliam B. Eerdmans Publishing Company, 1993), hal. 348

${ }^{7}$ Anthony A. Hoekma menuliskan dengan karakteristik perspektif nabi, para nabi Perjanjian Lama menggabungkan hal-hal yang berkaitan dengan kedatangan pertama Kristus dengan kedatangan-Nya yang kedua. Hal ini tidak akan jelas sebelum masa Perjanjian Baru. Melalui Perjanjian Barulah kita memahami bahwa apa yang dilihat sebagai kedatangan Mesias dalam Perjanjian Lama akan digenapi melalui dua tahap: kedatangan pertama dan kedua. (Anthony A. Hoekma, Alkitab Dan Akhir Zaman,...., hal. 14)
} 
penggenapan janji Allah di dalam pribadi dan karya Yesus Kristus yang menggenapai hukum Taurat (Alkitab PL dan PB) dan akhir dunia.

\section{PENGGENAPAN HUKUM TAURAT}

Pada kedatangan Yesus Kristus yang pertama merupakan penggenapan bagi pengharapan Iman orang-orang percaya dalam Perjanjian Lama. Anthony H. Hoekma menuliskan realitas eskatologis semua orang percaya dalam Perjanjian Lama (PL), yaitu: kedatangan Juruselamat, kerajaan Allah, Perjanjian (kovenan) baru, pemulihan bangsa Israel. pencurahan Roh Allah, Hari Tuhan, langit dan bumi yang baru. ${ }^{8}$ Hall Lindsey dalam bukunya tentang Penggenapan Janji Allah menuliskan beberapa penggenapan janji Allah pada kedatangan Yesus Kristus yang pertama, yaitu: keturunan perempuan, nubuat tentang anak Daud yang lebih agung, seorang nabi seperti Musa, lahir di Betlehem, dilahirkan seorang perawan, pengurapan oleh Roh, mujizat kesembuhan, penyerahan secara resmi, nubuat tentang pengkhianatan, dikhianati untuk tiga puluh uang perak, penderiataan-penderitaan Mesias, perubahan alam secara tiba-tiba dan besar, anak domba Allah, dikuburkan oleh seorang kaya, Ia bangkit, kenaikan Yesus ke surga. ${ }^{9}$ Dalam Alkitab konsep eskatologi dalam Perjanjian Lama berbicara tentang: hari Tuhan, yaitu: pertama, Visitasi Ilahi (Amos 5:18; Yoel 1:15) dan kedua,Visitasi Eskatologis (Yoel 3:14,18; Zef. 3:11,16; Zak. 14:6). Kehadiran Pribadi Mesias, yaitu: pertama, kerajaan Daud (Yes. 9:6,7; Yer. 23:5,6), kedua, Anak Manusia (Dan. 7,13,14) dan ketiga, hamba yang menderita (Yes. 53). ${ }^{10}$

Dalam Roma 10:4 menyatakan "Sebab Kristus adalah kegenapan hukum Taurat", sehingga kebenaran diperoleh tiap-tiap orang yang percaya". Dalam konteks ayat tersebut hukum Taurat menunjuk pada hukum yang diterima Musa di gunung Sinai. Jadi Kristus juga datang untuk menggenapi hukum Taurat di dalam diri-Nya, namun sesungguhnya Kristus tidak hanya menggenapi hukum Taurat yang di gunung Sinai tetapi seluruh hukum Taurat dalam PL. Jadi dapat disimpulkan penggenapan Yesus Kristus pada kedatangan-

\footnotetext{
8 Anthony A. Hoekma, Alkitab Dan,...., hal. 14

9 Hall Lindsey, Penggenapan Janji Allah (Bandung: Khalam Hidup, 1982), hal. 3

${ }^{10}$ Gunaryo Sudarmanto, Garis Besar Eskhatologi, diktat (Tanjung Enim: STTE, 2012), hal. 4

11 Istilah 'hukum Taurat' ditulis dalam bahasa Yunani no,moj (nomos). Istilah no,moj (nomos) memiliki beberapa penggunaan, yaitu: menunjuk pada seluruh atau sebagian hukum dari PL (Rm. 3:19), sistem pemerintahan yang Musa tetapkan di Sinai (Rm. 5:13, 20; Gal. 3:17,19,21a), hukum Allah sebagai penyataan dari kehendak Allah (Rm. 3:20;4:15; 7:2, 5, 7, 8, 9, 12, 16, 22), hukum yang secara khusus dinyatakan, dalam pertentangan dengan tuntutan mengenai pekerjaan baik yang sejak awal tertulis dalam hati manusia (Rm. 2:12-14), menunjuk pada orang yang menaruh perhatian kepada hukum dan untuk menggambarkan suatu asas yang berpengaruh dan yang menguasai (J.D Douglass, Ensiklopedi Alkitab Masa Kini Jilid I (Jakarta: Yayasan Komunikasi Bina Kasih (OMF), 1982), hal. 406-407)
} 
Nya yang pertama adalah Penggenapan saat ada di bumi yaitu: penggenapan nubuatan Mesianis dalam seluruh PL, penggenapan Hukum Taurat menunjuk pada penggenapan dalam pola kehidupan Yesus yang berhasil melakukan hukum Taurat tanpa cacat.

\section{$\underline{\text { Fakta-fakta Mesias dalam PL dan Penggenapan Mesianis }}$}

\section{Fakta Antropomorfisme dan Teopani}

Dalam PL penyataan tentang Mesias sudah jelas digambarkan, melalui penyataan antropomorfisme dan theophani. Penyataan antropomormisme (Antropos: manusia), artinya mengenakan ciri-ciri manusia kepada Allah. Antropomorfisme ada dua, yaitu Allah dinyatakan memiliki anggota tubuh (Bodily Anthrophism) Alkitab menuliskan Allah bisa melihat (Kej. 11:5), berbicara (Kej. 1:3), berjalan (Kej. 3:8), mendengar (Kej. 1:4), mencium (I Sam. 26:19), memiliki tangan (Yes. 50:11), kaki (Kel. 24:10), wajah (Bil. 6:25) dan Allah memiliki emosi dan intelektual (personality Antrophism) Alkitab menuliskan Allah bisa cemburu (Kel. 120:5), Marah (Maz. 102:11), Menyesal (Kej. 6:6), Mengasihi (Maz. 103:8), dan berpikir (Ams. 4:13). ${ }^{12}$ Menyatakan Allah sebagai pribadi maka Allah memiliki kecerdasan (intelligence), kesadaran atas diri sendiri (self consciousness), Penentuan diri sendiri (self determination). ${ }^{13}$ Penyataan Teofani (theos $=$ Allah, phainein = penampakan) adalah penampakan diri Allah. Ada tiga bentuk penampakan diri Allah, yaitu: manusia (human form) (Kej. 18:1-15), malaikat (angelic form) (Kej. 32:22-32), wujud lain (non human form). Jadi penyataan Allah secara antropomorfisme dan teopani bertujuan supaya manusia tidak terkejut bahwa Allah yang transenden sungguh-sungguh akan datang ke dunia dan hal itu tergenapi di dalam inkarnasi Yesus Kristus (Yoh. 1:14).

\section{Nubuat Kehidupan Mesias}

Fakta Perjanjian Lama tentang kehidupan Kristus juga sudah dipaparkan dalam nubuat-nubuat PL dan juga sudah digenapi dengan sangat jelas dalam fakta historis PB. Berikut beberapa fakta nubuatan tentang kehidupan Mesias dalam PL dan penggenapanNya dalam PB.

\section{$\underline{\text { Kelahiran Mesias }}$}

\footnotetext{
12 Gunaryo Sudarmanto, Kristologi 1, diktat (Tanjung Enim: STTE, 1999), hal. 6-7

13 J. fetcher Manafe, Doktrin Allah (Tanjung Enim: STTE, 2010), hal. 10
} 
Kelahiran Mesias (Kej. 3:15 digenapi dalam Gal. 4:4), yaitu melalui seorang dara (Yes. 7:14), daftar silsilah-Nya (Kej. 49:10; 2Sam. 7:16 digenapi dalam Mat. 1:1; Luk. 3:23) dan tempat kelahiran-Nya (Mik. 5:2 digenapi dalam Luk. 2:4-7). ${ }^{14}$

\section{Penyambutan Mesias}

Penyambutan Mesias yang masuk ke Yerusalem dengan menunggang keledai muda dinubuatkan dalam PL dalam Zakharia 9:9 yang digenapi dalam Markus 19:35-38.

\section{Pelayanan Mesias}

Pelayanan-Nya (Maz. 69:8-10; Yes. 9:1-2 digenapi dalam Mat. 4:14-16), dituliskan Ia adalah nabi yang akan datang (Ul. 18:15, 18, 19 di genapi dalam Kis. 3:20,22), Ia akan bertugas sebagai seorang Imam (Maz. 110:4 digenapi dalam Ibr. 5:5,6), Ia akan menjadi domba paskah (Kel. 12:46 digenapi dalam Yoh. 19:36). ${ }^{15}$ Karya Mesias yang dinubuatkan dalam PL yang digenapi dalam PB, yaitu: meredakan angin ribut (Maz. 107:29 digenapi dalam Mat. 8:23-27), Menyembuhkan orang buta (Maz. 146:8 digenapi dalam Yoh. 9:1-7), mengampuni dosa (Yes. 43:25; 44:42 digenapi dalam Mat. 9:2), membangkitkan orang mati (Maz. 49:15 digenapi dalam Mat. 9:25), memberi makan 5000 orang (Yoel 2:22-24 digenapi dalam Mat. 14:15-21). ${ }^{16}$

\section{Penderitaan Mesias}

Pdt Dr. Stephen Tong menuliskan tentang pemahaman istilah “.....segala sesuatu sudah terjadi...." dalam Yohanes 19:28 yang menunjukkan penggenapan mesianis dalam PL pada person Yesus Kristus. Ada sepuluh fakta penderitaan Mesias yang dinyatakan dan yang digenapi, yaitu: Dia dijual oleh kawan-Nya sendiri (Maz. 55:13-15 digenapi dalam Mat. 26:47-56), Dia akan dijual dengan tiga puluh keping perak (Zak. 11:12 digenapi dalam Mat. 26:15-16), Penggembala harus dibunuh dan domba-dombanya akan bercerai berai (zak. 13:7 di genapi dalam Mat. 26:56), Mesias akan dituduh dan difitnah oleh saksisaksi dusta (Maz. 109:2-5 digenapi dalam Mat. 27:12), Orang-orang akan mencambuk, memukuli, melukai serta meludahi muka-Nya (Yes. 53:3-8 digenapi dalam Mat. 26:67-68), Dia akan dihukum beserta dengan perampok-perampok (Yes. 53:9,15 digenapi dalam Mrk. 15:7, 28), Tangan dan kaki Mesias akan ditusuk (Maz. 22:16 digenapi dalam Yoh. 20:25-29), Pakaian-Nya akan direbut dan dibagi-bagi di antara orang-orang yang menyalibkan Dia (Maz. 22:18 digenapi dalam Yoh. 19:23-24), Dia berdoa untuk orang-

\footnotetext{
${ }^{14}$ Trivena Ambarsari, Doktrin Kristus (Surabaya: Momentum, 2011) hal, 10

15 Ibid,.., 10

16 Paul Enns, The Moody Hand Book Of Theology 1 (Malang: Literatur SAAT, 2004), hal. 283
} 
orang kriminal yang disalibkan bersama-sama dia (Yes. 53:12), Kegelapan menudungi Kristus (Ams. 8:9 digenapi dalam Mat. 27:45). ${ }^{17}$

\section{Kebangkitan Mesias dari Kematian}

Kebangkitan-Nya (Maz. 16:10 digenapi dalam Luk. 24:7; Kis. 2:24-28). ${ }^{18}$ Paul Enns menjelaskan nubuat Daud tentang kebangkitan Kristus (Mzr. 16:10); Petrus mengindikasikan kebangkitan Kristus menggenapi nubuat Mazmur 16:10. ${ }^{19}$

\section{$\underline{\text { Kenaikan Mesias Ke Surga }}$}

Kenaikan Mesias ke Sorga dan duduk disebelah kanan Allah dinubuatkan dalam Mazmur 110:1 yang digenapi dalam Markus 16:19.

Jadi kedatangan Yesus Kristus yang pertama adalah penggenapan tetang kehidupan Mesias yang sudah dinubuatkan dalam Perjanjian Lama. Oleh karena itu sesungguhnya rasul Paulus menjadi sangat yakin Yesus itulah Kristus karena Paulus benar-benar menegetahui Yesus yang dinubuatkan dalam PL. ${ }^{20}$ Sehingga ketika Paulus melihat dan mendengar tentang Yesus, ia langsung membukakan dan mengarahkan pemikirannya pada person Yesus yang adalah Kristus.

\section{Penggenapan Hukum Taurat Dalam Pola Kehidupan Yesus Kristus}

Istilah telos juga menunjuk pada Roma 10:4 yang menyatakan "Sebab Kristus adalah kegenapan hukum Taurat, sehingga kebenaran diperoleh tiap-tiap orang yang percaya". Charles C. Ryrie memberikan penjelasan tentang ayat tersebut, ia menyatakan kesudahan atau pun tujuan. Dengan kata lain Kristus telah menggenapi hukum Taurat, atau tujuan kedatangan Kristus untuk menggenapi hukum Taurat (Maz. 5:17). Meskipun benar bahwa Tuhan Yesus menggenapi hukum Taurat tetapi bagian ini tidak mengajarkan hal tersebut, yang diajarkan adalah bahwa Ia telah menggenapi hukum Taurat dan menyediakan cara hidup yang baru kepada Allah. ${ }^{21}$

Kedatangan Tuhan Yesus yang pertama telah menggenapi segala yang tertulis dalam hukum Taurat. Kehidupan moral Tuhan Yesus menunjukkan kehidupan moralitas ilahi yang tanpa dosa (lih. 1Pet. 2:22). Rasul Paulus menyatakan bahwa Kristus telah menebus orang percaya dari kutuk hukum Taurat agar berkat Abraham sampai kepada setiap suku-suku bangsa (lih. Gal. 3:13-14). Tuhan Yesus sendiri menyatakan bahwa Ia adalah penggenapan kitab Taurat Musa dan kitab nabi-nabi dan kitab Mazmur (Luk.

\footnotetext{
17 Sthephen Tong, 7 Perkataan Salib (Surabaya: Momentum, 2011), hal. 95-99

18 Trivena Ambarsari, Doktrin Kristus,....., hal. 10

19 Paul Enns, The Moody,..., hal. 287

20 Marlon Butar-Butar, Teologi Paulus (Tanjung Enim: STTE, 2012), hal. 25

${ }^{21}$ Charles C. Ryrie, Teologi Dasar II (Yogyakarta: Andi Offset, 2010), hal. 52
} 
24:44). Matthew Henry menjelaskan Lukas 24:44 bahwa Tuhan Yesus mengingatkan mereka akan firman yang telah mereka baca dalam Perjanjian Lama, seperti yang telah ditunjukkan oleh perkataan yang telah Ia ucapkan kepada mereka: Harus digenapi semua yang ada tertulis. Kristus telah memberikan sebuah petunjuk umum untuk mengarahkan harapan mereka, yaitu bahwa apa pun yang mereka dapati dalam Perjanjian Lama mengenai Mesias memang harus digenapi dalam diri-Nya, baik mengenai penderitaanNya. Segala hal mengenai diri-Nya Allah telah persatukan dalam semua nubuat tersebut, sehingga semua itu tidak boleh dipisahkan di dalam penggenapannya. Semuanya harus digenapi, bahkan yang terberat, tersulit, sampai yang paling menyakitkan. Kristus tidak boleh mati sebelum Dia mengalami semuanya itu, sebab jika tidak begitu, maka Ia tidak bisa berkata "sudah selesai." 22

Galatia 3:24 menyatakan "Jadi hukum Taurat adalah penuntun bagi kita sampai Kristus datang, supaya kita dibenarkan karena iman”. Dalam konteks Perjanjian Lama penebusan dosa harus ada pengorbanan. Syarat dalam pengorbanan tersebut pertobatan dari pribadi yang dinyatakan dengan memberikan korban domba yang jantan, yang sulung dan tidak bercacat. William Dyrness menuliskan hal tersebut melatarbelakangi rujukan pengorbanan Kristus dalam Efesus 5:2. ${ }^{23}$ Yesus adalah penggenapan korban penebusan dalam tipologi Perjanjian Lama, karena manusia yang berdosa harus ditebus oleh yang sebanding, yaitu manusia, manusia yang dikorbankan harus yang sulung, Yesus adalah manusia yang sulung satu-satunya karena Ia lahir dari seorang perawan bernama Maria. semua manusia telah berdosa ( $\mathrm{Rm}$. 3:23), Yesus adalah satu-satunya manusia yang suci tanpa dosa (1Pet. 2:22). Jadi hanya Yesus, manusia yang sempurna yang menggenapi kriteria korban penebusan dosa.

R.C. Sproul menjelaskan bahwa pada waktu inkarnasi, Anak menggambil rupa manusia supaya dapat menggenapi penebusan bagi keturunan Adam. Berdasarkan ketaatan-Nya yang sempurna, Kristus telah memuaskan tuntutan Hukum Allah dan telah mendapatkan hidup kekal bagi kita. ${ }^{24}$ Pendapat yang sama juga dipaparkan oleh Henry C. Thiessen yang menyatakan orang berdosa tidak dapat memenuhi tuntutan hukum ilahi, namun Kristus sebagai wakil dan pengganti kita, sanggup memenuhinya. Demikianlah, oleh ketaatan Kristus yang aktif dan pasif, Allah menyediakan pemenuhan tuntutan bagi

\footnotetext{
22 Tafsiran Matthew Henry Injil Lukas 13-24 (Surabaya: Momentum, 2009), hal. 909

hal. 134 William Dyrness, Tema-Tema Dalam Teologi Perjanjian Lama (Malang: Gandum Mas, 1990),

24 R.C. Sproul, Kebenaran-Kebenaran Dasar Iman Kristen (Malang: SAAT, 2007), hal. 133
} 
orang-orang berdosa (Rm. 8:3,4). ${ }^{25}$ Jadi kedatangan Tuhan Yesus yang pertama adalah penggenapan karya penebusan Allah bagi manusia berdosa yang ditetapkan menjadi umat pilihan Allah.

\section{PENGGENAPAN AKHIR ZAMAN}

Kedatangan Tuhan Yesus yang pertama telah menggenapi banyak nubuat-nubuat dalam Perjanjian Lama. Dalam terminologi menuliskan bahwa kata te,loj (telos) menunjuk juga pada 'akhir dunia' (lih. Mat. 24:6; 24:14, Mrk.13:7, Luk. 21:9, 1Kor. 10:11, 1Pet. 4:7, Why. 2:26). Tuhan Yesus juga menjanjikan penggenapan akhir zaman pada kedatanganNya yang kedua kali yang juga disebut penyempurnaan (consumasi). Jadi secara garis besar ada korelasi yang simultan dan progress antara penggenapan dan penyempurnaan. Menurut Louis Berkhof dan Henry C. Thiessen kedatangan Tuhan Yesus yang kedua dikategorikan dalam Eskatologi umum. Anthony H. Hoekma menggunakan istilah Eskatologi yang akan datang (future eschatology). ${ }^{26}$

Henry C. Thiessen menuliskan sepanjang Alkitab peristiwa kedatangan Kristus yang kedua kali memperoleh kedudukan yang penting. Sekalipun kedatangan yang pertama dan kedua sering digabungkan deengan begitu erat dalam nubuat PL sehingga sulit mengemukakan ayat-ayat yang secara khusus membahas tentang kedatangan Kristus yang kedua kali, namun ada beberapa ayat yang dengan jelas berbuat demikian (Ayb. 19:25, 26; Daniel 7:13, 14; Zakharia 14:4; Maleakhi 3:1,2). PB menyebut doktrin ini lebih dari tiga ratus kali. Bahkan ada pasal-pasal yang seluruhnya dipakai untuk memberitahukan kedatangan Kristus yang kedua kali ini (Mat. 24, 25; Mar. 13; Luk. 21; band. 1Kor. 15). Bahkan ada kitab-kitab tertentu yang secara khusus ditulis untuk membahas pokok ini (ITesalonika; IITesalonika; dan Kitab Wahyu). ${ }^{27}$ Jadi kedatangan Tuhan Yesus yang kedua kali adalah janji Tuhan Yesus yang akan digenapi pada kedatangan-Nya yang kedua kali.

\footnotetext{
25 Henry c. Thiessen, Teologi Sistematika (Malang: Gandum Mas, 1992), hal. 362

${ }^{26}$ Menurut Louis Berkhof ketika kita berbicara tentang eskatologi kita menyadari tentang kenyataan dan peristiwa yang berkaitan dengan kedatangan Kristus yang kedua kali dan peristiwa itu akan menandai akhir dari zaman ini dan membawa kita pada kemuliaan kekal di masa mendatang. (Louis Berkhof, Teologi Sistematika, Doktrin Tentang Akhiir Zaman, Surabaya: Momentum, 2010, hal. 12). Menurut Henry C. Thiessen eskatologi umum membahas peristiwa-peristiwa yang akan terjadi, mulai dari kedatangan Kristus yang kedua kali sampai penciptaan langit baru dan bumi baru (Henry c. Thiessen, Teologi Sistematika,..., hal. 519).

${ }^{27}$ Henry C. Thiessen, Teologi Sistematika,..., hal. 526
} 
Perjanjian lama menegaskan bahwa waktu penggenapan perjanjian tersebut akan terjadi dimasa depan (Yer. 31:31-40; Hos. 2:18-20). Rasul Paulus mempercayai keterangan Alkitab tersebut dan menganggap penggenapan Perjanjian Baru akan terjadi setelah kedatangan Kristus ke Bumi (Rm. 11:26-27). ${ }^{28}$ Paul Enns menjelaskan tentang pekerjaan Kristus di masa yang akan datang, ia menjelaskan pengharapan yang diperlihatkan di Kitab Suci merupakan restorasi terakhir dari segala sesuatu di bawah Mesias. Dalam satu fase kedatangan-Nya akan menggenapi pengharapan mulia dari gereja, suatu peristiwa kebangkitan dan reuni (1Kor. 15:51-58; 1Tes. 4:13-18; Tit. 2:13) dalam fase yang lain kedatangan-Nya akan merupakan penghakiman bagi bangsa yang tidak percaya dan setan (Why. 19:11-21), dan akan merupakan penyelamatan bagi umat-Nya, Israel (Mik. 5:4, Zak. 9:10). ${ }^{29}$

Jadi Kedatangan Tuhan Yesus yang kedua kali merupakan penggenapan janji Tuhan Yesus tentang akhir zaman yang akan menggenapi peristiwa kebangkitan (resurection), pengangkatan (rapture), perubahan (translation), penyiksaan (tribulasion) dan penghakiman (judgement) di akhir zaman. Menurut Millard J. Erickson Peristiwa ini merupakan dasar dari pengharapan orang Kristen, yaitu peristiwa yang merupakan awal dari puncak penggenapan rencana Allah. ${ }^{30}$

\section{KESIMPULAN}

Fullfilment (penggenapan) dalam konteks Alkitab dalam konsep eskatologi menunjuk pada penggenapan hukum Taurat dan akhir dunia yang memiliki korelasi yang berpusat pada pribadi dan karya Yesus Kristus. Jadi penggenapan hukum Taurat tentang pribadi dan karya Kristus di dalam PL berpusat pada Person Yesus Kristus yang dapat dilihat dari Fakta-fakta Mesias di dalam PL dan Penggenapan Mesianis di dalam PB. Fakta-fakta tersebut berupa fakta Antropomorfisme dan Teopani, nubuat kehidupan Mesias dan penggenapan Hukum Taurat Dalam Pola Kehidupan Yesus Kristus. Puncak penggenapan akhir dunia (akhir zaman) juga berpusat pada kedatangan Tuhan Yesus yang kedua kali, yang juga akan menggenapi peristiwa-peristiwa di akhir zaman yaitu kebangkitan (resurection), pengangkatan (rapture), perubahan (translation), penyiksaan (tribulasi) dan penghakiman (judgement) di akhir zaman.

\footnotetext{
28 Welly Pandesolang, Eskatologi Biblika (Yogyakarta: Andi Offset, 2009), hal. 19

29 Paul Enns, The Moody,...., hal. 295

${ }^{30}$ Millard J. Erickson, Teologi Kristen Volume III (Malang: Gandum Mas, 2004), hal. 508
} 


\section{DAFTAR PUSTAKA}

.... (2009). Tafsiran Matthew Henry Injil Lukas 13-24, Surabaya: Momentum

A. Hoekma, Anthony. (2004) Alkitab Dan Akhir Zaman, Surabaya: Momentum

Ambarsari, Trivena. (2011). Doktrin Kristus, Surabaya: Momentum.

Balzt, Balzt dan Gerhard Schneider. (1993). Exegetical Dictionary Of The New Testament $(E D N T)$, Michigan: Wiiliam B. Eerdmans Publishing Company.

Berkhof, Louis. (2010). Teologi Sistematika, Doktrin Tentang Akhiir Zaman, Surabaya: Momentum.

Butar-Butar, Marlon. (2012). Teologi Paulus, 'Diktat', Tanjung Enim: STTE.

C. Ryrie, Charles. (2010). Teologi Dasar II, Yogyakarta: Andi Offset.

C. Sproul, R. (2007). Kebenaran-Kebenaran Dasar Iman Kristen, Malang: SAAT.

C. Thiessen, Henry. (1992). Teologi Sistematika, Malang: Gandum Mas.

D Douglass, J. (1982). Ensiklopedi Alkitab Masa Kini Jilid I, Jakarta: Yayasan Komunikasi Bina Kasih (OMF).

Dyrness, William. (1990). Tema-Tema Dalam Teologi Perjanjian Lama, Malang: Gandum Mas.

Enns, Paull. (2004). The Moody Hand Book Of Theology 1, Malang: Literatur SAAT.

Fetchar Manafe, J. (2010). Doktrin Allah, 'Diktat', Tanjung Enim: STTE.

J. Erickson, Millard. (2004). Teologi Kristen Volume III, Malang: Gandum Mas.

Lindsey, Hall. (1982). Penggenapan Janji Allah, Bandung: Kalam Hidup.

Pandesolang, Welly. (2009). Eskatologi Biblika, Yogyakarta: Andi Offset

Sudarmanto, Gunaryo. (2012). Garis Besar Eskhatologi, diktat, Tanjung Enim: STTE (1999). Kristologi 1, diktat, Tanjung Enim: STTE

Sutanto, Hasan. (2010). Perjanjian Baru Interlinear Yunani-Indonesia dan Konkordansi Perjanjian baru (PBIK) Jilid II, Jakarta: LAI

Ten Napel, Henk. (2002). Kamus Theologi, Jakarta: BPK Gunung Mulia

Tim Prima Pena. (....). KBBI: Gita Media Press

Tong, Stephen. (2011). 7 Perkataan Salib, Surabaya: Momentum 